\title{
Receptor guanylyl cyclase (RGC) family in GtoPdb v.2021.3
}

Annie Beuve ${ }^{1}$, Peter Brouckaert ${ }^{2}$, John C. Burnett, Jr. ${ }^{3}$, Andreas Friebe ${ }^{4}$, John Garthwaite ${ }^{5}$, Adrian J. Hobbss $^{6}$, Doris Koesling ${ }^{7}$, Michaela Kuhn ${ }^{8}$, Lincoln R. Potter ${ }^{9}$, Michael Russwurm ${ }^{10}$, Harald H.H.W. Schmidt $^{11}$, Johannes-Peter Stasch ${ }^{12}$ and Scott A. Waldman ${ }^{13}$

1. Rutgers University, USA

2. Vlaams Instituut voor Biotechnologie, Belgium

3. Mayo Clinic, USA

4. Universität Würzburg, Germany

5. University College London, UK

6. Queen Mary University of London, UK

7. Ruhr-Universität Bochum, Germany

8. Physiologisches Institut der Universität Würzburg, Germany

9. University of Minnesota, USA

10. Ruhr University Bochum, Germany

11. Maastricht University, The Netherlands

12. Bayer AG, Germany

13. Thomas Jefferson University, USA

\begin{abstract}
The mammalian genome encodes seven guanylyl cyclases, GC-A to GC-G, that are homodimeric transmembrane receptors activated by a diverse range of endogenous ligands. These enzymes convert guanosine-5'-triphosphate to the intracellular second messenger cyclic guanosine-3',5'monophosphate (cyclic GMP). GC-A, GC-B and GC-C are expressed predominantly in the cardiovascular system, skeletal system and intestinal epithelium, respectively. GC-D and GC-G are found in the olfactory neuropepithelium and Grueneberg ganglion of rodents, respectively. GC-E and GC-F are expressed in retinal photoreceptors.
\end{abstract}

\section{Contents}

This is a citation summary for Receptor guanylyl cyclase (RGC) family in the Guide to Pharmacology database (GtoPdb). It exists purely as an adjunct to the database to facilitate the recognition of citations to and from the database by citation analyzers. Readers will almost certainly want to visit the relevant sections of the database which are given here under database links.

GtoPdb is an expert-driven guide to pharmacological targets and the substances that act on them. GtoPdb is a reference work which is most usefully represented as an on-line database. As in any publication this work should be appropriately cited, and the papers it cites should also be recognized. This document provides a citation for the relevant parts of the database, and also provides a reference list for the research cited by those parts. For further details see [2].

Please note that the database version for the citations given in GtoPdb are to the most recent preceding version in which the family or its subfamilies and targets were substantially changed. The links below are to the current version. If you need to consult the cited version, rather than the most recent version, please contact the GtoPdb curators.

\section{Database links}

Receptor guanylyl cyclase (RGC) family

https://www.guidetopharmacology.org/GRAC/FamilyDisplayForward?familyId=1022

Transmembrane guanylyl cyclases

https://www.guidetopharmacology.org/GRAC/FamilyDisplayForward?familyId=662

Receptors

GC-A(Guanylyl cyclase-A) 
https://www.guidetopharmacology.org/GRAC/ObjectDisplayForward?objectId=1747 GC-B(Guanylyl cyclase-B)

https://www.guidetopharmacology.org/GRAC/ObjectDisplayForward?objectId=1748 GC-C(Guanylyl cyclase-C)

https://www.guidetopharmacology.org/GRAC/ObjectDisplayForward?objectId=1750 NPR-C(natriuretic peptide receptor 3)

https://www.guidetopharmacology.org/GRAC/ObjectDisplayForward?objectId=1749 GC-D(Guanylyl cyclase-D)

https://www.guidetopharmacology.org/GRAC/ObjectDisplayForward?objectId=2898 GC-E(Guanylyl cyclase-E)

https://www.guidetopharmacology.org/GRAC/ObjectDisplayForward?objectId=2031 GC-F(Guanylyl cyclase-F)

https://www.guidetopharmacology.org/GRAC/ObjectDisplayForward?objectId=2899 GC-G(Guanylyl cyclase-G)

https://www.guidetopharmacology.org/GRAC/ObjectDisplayForward?objectId=2900 Nitric oxide (NO)-sensitive (soluble) guanylyl cyclase

https://www.guidetopharmacology.org/GRAC/FamilyDisplayForward?familyId=939

Receptors

Complexes

GC-1(Guanylyl cyclase, $\alpha_{1} \beta_{1}$ )

https://www.guidetopharmacology.org/GRAC/ObjectDisplayForward?objectId=1287 GC-2(Guanylyl cyclase, $\alpha_{2} \beta_{1}$ )

https://www.guidetopharmacology.org/GRAC/ObjectDisplayForward?objectId=2897

Receptors and Subunits

Guanylyl cyclase $\alpha_{1}$ subunit

https://www.guidetopharmacology.org/GRAC/ObjectDisplayForward?objectId=1288 Guanylyl cyclase $\alpha_{2}$ subunit

https://www.guidetopharmacology.org/GRAC/ObjectDisplayForward?objectId=1289 Guanylyl cyclase $\beta_{1}$ subunit

https://www.guidetopharmacology.org/GRAC/ObjectDisplayForward?objectId=1290 Guanylyl cyclase $\beta_{2}$ subunit

https://www.guidetopharmacology.org/GRAC/ObjectDisplayForward?objectId=1291

\section{References}

1. Bach T, Bergholtz S, Riise J, Qvigstad E, Skomedal T, Osnes JB and Levy FO. (2014) Identification of small molecule NPR-B antagonists by high throughput screening--potential use in heart failure. Naunyn Schmiedebergs Arch Pharmacol 387: 5-14 [PMID:24297249]

2. Buneman P, Christie G, Davies JA, Dimitrellou R, Harding SD, Pawson AJ, Sharman JL and Wu Y. (2020) Why data citation isn't working, and what to do about it Database $\mathbf{2 0 2 0}$ [PMID:32367113]

3. Busby RW, Bryant AP, Bartolini WP, Cordero EA, Hannig G, Kessler MM, Mahajan-Miklos S, Pierce CM, Solinga RM and Sun LJ et al.. (2010) Linaclotide, through activation of guanylate cyclase $\mathrm{C}$, acts locally in the gastrointestinal tract to elicit enhanced intestinal secretion and transit. Eur J Pharmacol 649: 328-35 [PMID:20863829]

4. Buys ES, Zimmer DP, Chickering J, Graul R, Chien YT, Profy A, Hadcock JR, Masferrer JL and Milne GT. (2018) Discovery and development of next generation sGC stimulators with diverse multidimensional pharmacology and broad therapeutic potential. Nitric Oxide 78: 72-80 [PMID:29859918]

5. Chao YC, Chen CC, Lin YC, Breer H, Fleischer J and Yang RB. (2015) Receptor guanylyl cyclase$\mathrm{G}$ is a novel thermosensory protein activated by cool temperatures. EMBO J 34: 294-306 [PMID:25452496]

6. Chao YC, Cheng CJ, Hsieh HT, Lin CC, Chen CC and Yang RB. (2010) Guanylate cyclase-G, expressed in the Grueneberg ganglion olfactory subsystem, is activated by bicarbonate. Biochem J 432: 267-73 [PMID:20738256]

7. Delporte C, Poloczek P, Gossen D, Tastenoy M, Winand J and Christophe J. (1991) Characterization and regulation of atrial natriuretic peptide (ANP)-R1 receptors in the human neuroblastoma cell line NB-OK-1. Eur J Pharmacol 207: 81-8 [PMID:1680722]

8. Deschênes J, Duperé C, McNicoll N, L'Heureux N, Auger F, Fournier A and De Léan A. (2005) Development of a selective peptide antagonist for the human natriuretic peptide receptor-B. Peptides 26: 517-24 [PMID:15652659]

9. Edelson JD, Makhlina M, Silvester KR, Vengurlekar SS, Chen X, Zhang J, Koziol-White CJ, Cooper PR, Hallam TJ and Hay DW et al.. (2013) In vitro and in vivo pharmacological profile of PL-3994, a novel cyclic peptide (Hept-cyclo(Cys-His-Phe-d-Ala-Gly-Arg-d-Nle-Asp-Arg-Ile-SerCys)-Tyr-[Arg mimetic]-NH(2)) natriuretic peptide receptor-A agonist that is resistant to neutral 
endopeptidase and acts as a bronchodilator. Pulm Pharmacol Ther 26: 229-38 [PMID:23154072]

10. Feelisch M, Kotsonis P, Siebe J, Clement B and Schmidt HH. (1999) The soluble guanylyl cyclase inhibitor $1 \mathrm{H}-[1,2,4]$ oxadiazolo[4,3,-a] quinoxalin-1-one is a nonselective heme protein inhibitor of nitric oxide synthase and other cytochrome P-450 enzymes involved in nitric oxide donor bioactivation. Mol Pharmacol 56: 243-53 [PMID:10419542]

11. Follmann M, Ackerstaff J, Redlich G, Wunder F, Lang D, Kern A, Fey P, Griebenow N, Kroh W and Becker-Pelster EM et al.. (2017) Discovery of the Soluble Guanylate Cyclase Stimulator Vericiguat (BAY 1021189) for the Treatment of Chronic Heart Failure. J Med Chem 60: 51465161 [PMID:28557445]

12. Friebe A, Müllershausen F, Smolenski A, Walter U, Schultz G and Koesling D. (1998) YC-1 potentiates nitric oxide- and carbon monoxide-induced cyclic GMP effects in human platelets. Mol Pharmacol 54: 962-7 [PMID:9855623]

13. Friebe A, Schultz G and Koesling D. (1996) Sensitizing soluble guanylyl cyclase to become a highly CO-sensitive enzyme. EMBO J 15: 6863-8 [PMID:9003762]

14. Galle J, Zabel U, Hübner U, Hatzelmann A, Wagner B, Wanner C and Schmidt HH. (1999) Effects of the soluble guanylyl cyclase activator, YC-1, on vascular tone, cyclic GMP levels and phosphodiesterase activity. Br J Pharmacol 127: 195-203 [PMID:10369473]

15. Garthwaite J, Southam E, Boulton CL, Nielsen EB, Schmidt K and Mayer B. (1995) Potent and selective inhibition of nitric oxide-sensitive guanylyl cyclase by $1 \mathrm{H}-[1,2,4]$ oxadiazolo[4,3a]quinoxalin-1-one. Mol Pharmacol 48: 184-8 [PMID:7544433]

16. Hamra FK, Eber SL, Chin DT, Currie MG and Forte LR. (1997) Regulation of intestinal uroguanylin/guanylin receptor-mediated responses by mucosal acidity. Proc Natl Acad Sci USA 94: 2705-10 [PMID:9122260]

17. Harris LA and Crowell MD. (2007) Linaclotide, a new direction in the treatment of irritable bowel syndrome and chronic constipation. Curr Opin Mol Ther 9: 403-10 [PMID:17694454]

18. Hobbs A, Foster P, Prescott C, Scotland R and Ahluwalia A. (2004) Natriuretic peptide receptor$\mathrm{C}$ regulates coronary blood flow and prevents myocardial ischemia/reperfusion injury: novel cardioprotective role for endothelium-derived C-type natriuretic peptide. Circulation 110: 12315 [PMID:15337698]

19. Horst BG, Yokom AL, Rosenberg DJ, Morris KL, Hammel M, Hurley JH and Marletta MA. (2019) Allosteric activation of the nitric oxide receptor soluble guanylate cyclase mapped by cryoelectron microscopy. Elife 8 [PMID:31566566]

20. Hu J, Zhong C, Ding C, Chi Q, Walz A, Mombaerts P, Matsunami H and Luo M. (2007) Detection of near-atmospheric concentrations of $\mathrm{CO} 2$ by an olfactory subsystem in the mouse. Science 317: 953-7 [PMID:17702944]

21. Kambayashi Y, Nakajima S, Ueda M and Inouye K. (1989) A dicarba analog of beta-atrial natriuretic peptide (beta-ANP) inhibits guanosine 3',5'-cyclic monophosphate production induced by alpha-ANP in cultured rat vascular smooth muscle cells. FEBS Lett 248: 28-34 [PMID:2542088]

22. Kang Y, Liu R, Wu JX and Chen L. (2019) Structural insights into the mechanism of human soluble guanylate cyclase. Nature 574: 206-210 [PMID:31514202]

23. Ko FN, Wu CC, Kuo SC, Lee FY and Teng CM. (1994) YC-1, a novel activator of platelet guanylate cyclase. Blood 84: 4226-33 [PMID:7527671]

24. Lorget F, Kaci N, Peng J, Benoist-Lasselin C, Mugniery E, Oppeneer T, Wendt DJ, Bell SM, Bullens S and Bunting S et al.. (2012) Evaluation of the therapeutic potential of a CNP analog in a Fgfr3 mouse model recapitulating achondroplasia. Am J Hum Genet 91: 1108-14 [PMID:23200862]

25. Maack T, Suzuki M, Almeida FA, Nussenzveig D, Scarborough RM, McEnroe GA and Lewicki JA. (1987) Physiological role of silent receptors of atrial natriuretic factor. Science 238: 675-8 [PMID:2823385]

26. Martin FL, Sangaralingham SJ, Huntley BK, McKie PM, Ichiki T, Chen HH, Korinek J, Harders GE and Burnett Jr JC. (2012) CD-NP: a novel engineered dual guanylyl cyclase activator with anti-fibrotic actions in the heart. PLoS ONE 7: e52422 [PMID:23272242]

27. Mathur D, Root AR, Bugaj-Gaweda B, Bisulco S, Tan X, Fang W, Kearney JC, Lucas J, Guffroy M and Golas J et al.. (2020) A Novel GUCY2C-CD3 T-Cell Engaging Bispecific Construct (PF07062119) for the Treatment of Gastrointestinal Cancers. Clin Cancer Res 26: 2188-2202 [PMID:31996389]

28. McKie PM, Cataliotti A, Huntley BK, Martin FL, Olson TM and Burnett Jr JC. (2009) A human atrial natriuretic peptide gene mutation reveals a novel peptide with enhanced blood pressurelowering, renal-enhancing, and aldosterone-suppressing actions. J Am Coll Cardiol 54: 1024-32 [PMID:19729120]

29. Moffatt P, Thomas G, Sellin K, Bessette MC, Lafrenière F, Akhouayri O, St-Arnaud R and Lanctôt C. (2007) Osteocrin is a specific ligand of the natriuretic Peptide clearance receptor that modulates bone growth. J Biol Chem 282: 36454-62 [PMID:17951249]

30. Morishita Y, Sano T, Ando K, Saitoh Y, Kase H, Yamada K and Matsuda Y. (1991) Microbial 
polysaccharide, HS-142-1, competitively and selectively inhibits ANP binding to its guanylyl cyclase-containing receptor. Biochem Biophys Res Commun 176: 949-57 [PMID:1674870]

31. Murthy KS and Makhlouf GM. (1999) Identification of the G protein-activating domain of the natriuretic peptide clearance receptor (NPR-C). J Biol Chem 274: 17587-92 [PMID:10364194]

32. Nam SS, Greenfield EA, O'Keefe TL, Qin S and Babcock J.. (2014) Anti-GCC antibody molecules and related compositions and methods. Patent number: US8785600 B2.

33. Olesen SP, Drejer J, Axelsson O, Moldt P, Bang L, Nielsen-Kudsk JE, Busse R and Mülsch A. (1998) Characterization of NS 2028 as a specific inhibitor of soluble guanylyl cyclase. $\mathrm{Br} \mathrm{J}$ Pharmacol 123: 299-309 [PMID:9489619]

34. Olson LJ, Lowe DG and Drewett JG. (1996) Novel natriuretic peptide receptor/guanylyl cyclase A-selective agonist inhibits angiotensin II- and forskolin-evoked aldosterone synthesis in a human zona glomerulosa cell line. Mol Pharmacol 50: 430-5 [PMID:8700153]

35. Russwurm M, Behrends S, Harteneck C and Koesling D. (1998) Functional properties of a naturally occurring isoform of soluble guanylyl cyclase. Biochem J 335 ( Pt 1): 125-30 [PMID:9742221]

36. Schindler U, Strobel H, Schönafinger K, Linz W, Löhn M, Martorana PA, Rütten H, Schindler PW, Busch AE and Sohn M et al.. (2006) Biochemistry and pharmacology of novel anthranilic acid derivatives activating heme-oxidized soluble guanylyl cyclase. Mol Pharmacol 69: 1260-8 [PMID:16332991]

37. Shailubhai K, Comiskey S, Foss JA, Feng R, Barrow L, Comer GM and Jacob GS. (2013) Plecanatide, an oral guanylate cyclase $\mathrm{C}$ agonist acting locally in the gastrointestinal tract, is safe and well-tolerated in single doses. Dig Dis Sci 58: 2580-6 [PMID:23625291]

38. Shailubhai K, Palejwala V, Arjunan KP, Saykhedkar S, Nefsky B, Foss JA, Comiskey S, Jacob GS and Plevy SE. (2015) Plecanatide and dolcanatide, novel guanylate cyclase-C agonists, ameliorate gastrointestinal inflammation in experimental models of murine colitis. World $J$ Gastrointest Pharmacol Ther 6: 213-22 [PMID:26558155]

39. Singh G, Kuc RE, Maguire JJ, Fidock M and Davenport AP. (2006) Novel snake venom ligand dendroaspis natriuretic peptide is selective for natriuretic peptide receptor-A in human heart: downregulation of natriuretic peptide receptor-A in heart failure. Circ Res 99: 183-90 [PMID:16778132]

40. Stasch JP, Becker EM, Alonso-Alija C, Apeler H, Dembowsky K, Feurer A, Gerzer R, Minuth T, Perzborn E and Pleiss U et al.. (2001) NO-independent regulatory site on soluble guanylate cyclase. Nature 410: 212-5 [PMID:11242081]

41. Stasch JP and Hobbs AJ. (2009) NO-independent, haem-dependent soluble guanylate cyclase stimulators. Handb Exp Pharmacol: 277-308 [PMID:19089334]

42. Stasch JP, Schmidt P, Alonso-Alija C, Apeler H, Dembowsky K, Haerter M, Heil M, Minuth T, Perzborn E and Pleiss U et al.. (2002) NO- and haem-independent activation of soluble guanylyl cyclase: molecular basis and cardiovascular implications of a new pharmacological principle. $\mathrm{Br}$ J Pharmacol 136: 773-83 [PMID:12086987]

43. Suga S, Nakao K, Hosoda K, Mukoyama M, Ogawa Y, Shirakami G, Arai H, Saito Y, Kambayashi Y and Inouye K. (1992) Receptor selectivity of natriuretic peptide family, atrial natriuretic peptide, brain natriuretic peptide, and C-type natriuretic peptide. Endocrinology 130: 229-39 [PMID:1309330]

44. Tobin JV, Zimmer DP, Shea C, Germano P, Bernier SG, Liu G, Long K, Miyashiro J, Ranganath S and Jacobson S et al.. (2018) Pharmacological Characterization of IW-1973, a Novel Soluble Guanylate Cyclase Stimulator with Extensive Tissue Distribution, Antihypertensive, AntiInflammatory, and Antifibrotic Effects in Preclinical Models of Disease. J Pharmacol Exp Ther 365: 664-675 [PMID:29643251]

45. Veale CA, Alford VC, Aharony D, Banville DL, Bialecki RA, Brown FJ, Damewood JR, Dantzman CL, Edwards PD and Jacobs RT et al.. (2000) The discovery of non-basic atrial natriuretic peptide clearance receptor antagonists. Part 1. Bioorg Med Chem Lett 10: 1949-52 [PMID:10987424]

46. Weber W, Fischli W, Hochuli E, Kupfer E and Weibel EK. (1991) Anantin--a peptide antagonist of the atrial natriuretic factor (ANF). I. Producing organism, fermentation, isolation and biological activity. J Antibiot 44: 164-71 [PMID:1849131]

47. Wobst J, Schunkert H and Kessler T. (2018) Genetic alterations in the NO-cGMP pathway and cardiovascular risk. Nitric Oxide 76: 105-112 [PMID:29601927]

48. Wyss DF, Lahm HW, Manneberg M and Labhardt AM. (1991) Anantin--a peptide antagonist of the atrial natriuretic factor (ANF). II. Determination of the primary sequence by NMR on the basis of proton assignments. J Antibiot 44: 172-80 [PMID:1826288]

49. Zabel U, Weeger M, La M and Schmidt HH. (1998) Human soluble guanylate cyclase: functional expression and revised isoenzyme family. Biochem J 335 ( Pt 1): 51-7 [PMID:9742212] 